\title{
Pengaruh Kondisi Kesehatan Lingkungan Terhadap Kepuasan dan Jumlah Kunjungan Pasien di Puskesmas Kota Pekanbaru
}

\author{
Mailinda Sulistiawati ${ }^{1}$, Zulkarnaini $^{2}$, Zahtamal $^{3}$ \\ ${ }^{1}$ Seksi Pencegahan dan penanggulangan penyakit, Dinas Kesehatan Provinsi Riau, Pekanbaru \\ ${ }^{2}$ Program Studi Ilmu Lingkungan Universitas Riau Jl. Pattimura No.09.Gobah, 28131. Telp 0761-23742 \\ ${ }^{3}$ Fakultas Kedokteran Universitas Riau Jalan Diponegoro No. 01 Pekanbaru Riau
}

\begin{abstract}
Given the importance of environmental health at puskesmas in the environmental health care system to create a healthy environment that can provide protection for patients and puskesmas. This study aims to analyze the partial and simultaneous influence between the buildings outside, building in the building, sanitation facilities and hygiene management on environmental health condition, analyze the effect of Puskesmas environment condition to the satisfaction and number of patient visit at Pekanbaru Health Center. This study used survey methods conducted at all public health centers in Pekanbaru City from April to August 2017. The sample size was 20 Puskesmas and 400 patients visited the Puskesmas. The tools and materials used in this research are observation instruments and use checklists and questionnaire interview instruments (questionnaires). The partial simultaneous effect of outbuildings, in-building buildings, sanitation facilities and hygiene management on the health condition of the puskesmas was used multiple regression tests, with the result of correlation of the condition of outsides to 0.321 outbuildings, buildings in 0.834 , sanitation facilities 0.876 and cleanliness management 0.640. The direction of positive relationships shows the greater the assessment of the four variables will increasingly make the score of environmental health assessments getting bigger as well. Influence of health condition of environment of puskesmas toward patient satisfaction using multiple linear regression test and the result is 0,669. This shows a strong influence between environment health variable of puskesmas and satisfaction of respondent who come to visit puskesmas. $R$ Square 0,448 or coefficient of determination mean 44,8\% satisfaction of respondent can be explained by environment health variable of puskesmas. The influence of health condition of puskesmas on the number of patient visit using simple linear regression test and the result is 0,628. This shows a strong correlation between environment health variables of puskesmas with respondent visit coming to visit puskesmas. $R$ Square 0,394 or coefficient of determination mean 39,4\% of respondent visit can be explained by environment health variable of puskesmas while the rest is explained by other cause. It is necessary to increase health promotion and education about the importance of environmental health of puskesmas for the community about the health condition of the environment that fulfill the health requirement and increasing the role of Dinas Kesehatan in supervision of health of puskesmas environment to be better and become the reference of accreditation of puskesmas according to standard from the Ministry of Health RI.
\end{abstract}

Key Words: Number of Patient Visits, Environmental Health, Patient Satisfaction

Kesehatan lingkungan sebagai salah satu upaya kesehatan ditujukan untuk mewujudkan kualitas lingkungan yang sehat, baik fisik, kimia, biologi, maupun sosial yang memungkinkan setiap orang mencapai derajat kesehatan yang setinggi-tingginya, sebagaimana tercantum dalam Pasal 162 Undang-Undang Nomor 36 Tahun 2009 tentang Kesehatan. Ketentuan mengenai penyelenggaraan kesehatan lingkungan selanjutnya diatur dalam Peraturan Pemerintah Nomor 66 Tahun 2014 tentang Kesehatan Lingkungan, yang pengaturannya ditujukan dalam rangka terwujudnya kualitas lingkungan yang sehat, melalui upaya pencegahan penyakit dan/atau gangguan kesehatan dari faktor risiko kesehatan 
lingkungan di permukiman, tempat kerja, tempat rekreasi serta tempat fasilitas umum (Slamet, 2004).

Dalam rangka meningkatkan kemampuan memberikan pelayanan yang bermutu pada masyarakat ini, berbagai upaya telah dilakukan oleh pemerintah. Sampai saat ini hasilnya telah ditunjukkan oleh pengadaan fasilitas kesehatan seperti puskesmas. Kemajuan yang telah dicapai sudah menampakkan kondisi sebagaimana yang diharapkan. Melihat kenyataan ini harus diakui bahwa upaya pemerintah hingga sekarang telah berhasil meningkatkan pengadaan jumlah Puskesmas di Indonesia (Djojosugito, 2001).Namun demikian, harus diakui bahwa upaya memberikan pelayanan kesehatan yang bermutu masih perlu mendapat perhatian. Salah satu indikator tentang perlunya memperhatikan hygiene dan sanitasi Puskesmas. Berdasarkan data statistik, jumlah Puskesmas di Indonesia pada tahun 2014 adalah 9.731 unit. Jumlah puskesmas ini mengalami peningkatan sebanyak 76 unit dibandingkan tahun 2013 yang berjumlah 9.665 unit. Faktor - faktor yang mempengaruhi kepuasan pasien dalam pelayanan kesehatan diantaranya adalah kualitas pelayanan dan kondisi kesehatan lingkungan Puskesmas.

Survei awal yang dilakukan peneliti pada tiga Puskesmas di Kota Pekanbaru, kondisi kesehatan lingkungan Puskesmas yang terdiri dari beberapa variabel diantaranya bangunan luar gedung, bangunan dalam gedung, sarana fasilitas sanitasi, manajemen kebersihan dan ketertiban serta adanya ruang tambahan saat ini sebagian besar belum memenuhi syarat kesehatan sesuai dengan permenkes No 1428 tahun 2006. Di dalam variabel manajemen kebersihan dan ketertiban adanya Penilaian Puskesmas Bersih dan Tertib (PPBT) terhadap mutu dan kualitas pelayanan yang diberikan oleh petugas kepada pengunjung puskesmas,namun kondisi pada saat ini masih ada beberapa puskesmas di kota Pekanbaru yang belum memenuhi penilaian PPBT. Berdasarkan hal tersebut, maka peneliti merasa tertarik untuk melakukan penelitian ini. Penelitian ini dilakukan di Puskesmas yang ada di Kota Pekanbaru dengan alasan bahwa Puskesmas di Kota Pekanbaru dalam penyelenggaraannya belum dilakukan penilaian tentang kesehatan lingkungan sebagaimana yang diatur dalam Permenkes No. 1428 Tahun 2006 tentang Pedoman Penyelenggaraan Kesehatan Lingkungan Puskesmas.

\section{BAHAN DAN METODE}

Penelitian ini dilakukan pada bulan April sampai dengan Agustus 2017. Kuesioner dalam penelitian ini berupa seperangkat pertanyaan tertutup yang diberikan kepada responden secara langsung dengan pilihan jawaban yang telah disediakan menggunakan skala likert yaitu masing-masing item pernyataan memiliki nilai 1-4 dengan pilihan jawaban seperti Sangat Tidak Setuju (STS), Tidak Setuju (TS), Setuju (S) dan Sangat Setuju (SS).

Kuesioner digunakan untuk mengukur variabel kepuasan pasien terhadap kondisi kesehatan lingkungan puskesmas. Kuesioner untuk menilia kepuasan pasien ini terdiri dari 25 item pernyataan yang dibagi dalam beberapa kelompok yaitu 5 item pernyataan untuk kepuasan pasien terhadap bangunan luar puskesmas, 5 item pernyataan untuk kepuasan terhadap bangunan dalam, 5 item pernyataan untuk kepuasan terhadap sarana sanitasi dan 10 pernyataan untuk kepuasan terhadap mutu pelayanan. Sampel adalah sebagian dari jumlah dan karakteristik yang dimiliki populasi tersebut. Pada penelitian ini digunakan 2 (dua) populasi sehingga jumlah sampel yang digunakan juga terdiri dari 2 (dua) unit yaitu: untuk sampel puskesmas yang digunakan dalam penelitian ini adalah 20 puskesmas atau total sampling yang berarti semua populasi dijadikan sampel penelitian. Sedangkan untuk sampel pasien yang digunakan adalah keseluruhan pasien yang kebetulan dijumpai peneliti pada saat penelitian yang dilakukan pada bulan april sampai dengan mei tahun 2017 atau dengan teknik accidental sampling. Untuk mengetahui pengaruh simultan dan parsial antara bangunan luar gedung, bangunan dalam gedung, sarana sanitasi, manajemen kebersihan dan ketertiban dan ruang tambahan terdahap kondisi kesehatan lingkungan puskemas, analisa data yang digunakan adalah regresi linear berganda. Namun sebelum melakukan analisis regresi linear berganda terlebih dahulu dilakukan uji asumsi klasik yaitu uji normalitas, uji multikolinearitas, Uji heteroskedastisitas, selanjutnya dilakukan analisis regresi berganda 
yaitu analisis korelasi ganda (R) dan analisis determinasi. Sedangkan untuk mengetahui pengaruh kondisi kesehatan lingkungan puskemas terhadap kepuasan pasien dilakukan analisa regresi linear sederhana. Untuk mengetahui pengaruh kondisi kesehatan lingkungan puskemas terhadap kunjungan pasien dilakukan analisa regresi linear sederhana.

\section{HASIL}

\section{Karakteristik responden}

Berdasarkan kelompok umur responden yang terbanyak adalah usia 36 - 49 tahun dengan frekuensi 159 orang $(39.8 \%)$ dan kelompok umur responden yang terkecil adalah usia dibawah 20 tahun dengan frekuensi 19 orang $(4.8 \%)$. Umumnya responden berusia produktif ( 20 - 49 tahun).

Tabel 1. Distribusi Responden Menurut Tingkat Pendidikan

\begin{tabular}{llcc}
\hline No & Pendidikan & Jumlah & Persentase $(\%)$ \\
\hline 1 & Tamat SD & 44 & 11,10 \\
2 & Tamat SLTP & 117 & 29,20 \\
3 & Tamat SLTA & 179 & 44,80 \\
4 & PT & 60 & 14.90 \\
\hline & Jumlah & 400 & 100,00
\end{tabular}

Berdasarkan tabel 1 diketahui bahwa sebagian besar responden di puskesmas berpendidikan SLTA atau sederajat. Dengan persentase sebesar $44,80 \%$. Hal ini menunjukkan bahwa tingkat pendidikan responden sudah cukup tinggi. Namun masih ada juga yang berpendidikan sekolah dasar dengan persentase sebesar $11.1 \%$. Hal ini berpengaruh pada tingkat pengetahuan responden dalam memandang dan menilai pentingnya kesehatan lingkungan puskesmas.

Tabel 2. Distribusi Responden Menurut Jenis Kelamin

\begin{tabular}{llcc}
\hline No & Pekerjaan & Jumlah & Persentase $(\%)$ \\
\hline 1 & Tidak Bekerja & 213 & 53,25 \\
2 & Wiraswasta & 72 & 18,00 \\
3 & Petani & 21 & 5,20 \\
4 & PNS/TNI/POLRI & 14 & 3,50 \\
5 & Lain - lain & 80 & 20,00 \\
\hline & Jumlah & 400 & 100 \\
\hline
\end{tabular}

Berdasarkan Tabel 2, hasil distribusi karakteristik responden dapat diketahui bahwa pekerjaan responden terbesar adalah Ibu Rumah Tangga (IRT) dengan jumlah 192 orang dengan persentase $48,00 \%$. Sedangkan yang terkecil jenisnya adalah PNS/TNI/POLRI dengan jumlah 14 orang $(3,5 \%)$. Dengan melihat distribusi tersebut dapat disimpulkan bahwa layanan puskesmas banyak dimanfaatkan oleh masyarakat kalangan menengah ke bawah. Hal ini dimungkinkan bagi masyarakat yang mampu secara ekonomi akan memilih rumah sakit atau dokter praktek pribadi untuk mendapatkan pelayanan yang lebih baik, mengingat di puskesmas selama ini masih dianggap pelayanan kurang memuaskan, obat yang digunakan juga masih obat generik dan juga ada alasan gengsi.

Tabel 3. Distribusi Responden Menurut Jenis Kelamin

\begin{tabular}{llcc}
\hline No & Jenis Kelamin & Jumlah & Persentase (\%) \\
\hline 1 & Laki - laki & 129 & 32,20 \\
2 & Perempuan & 271 & 67,80 \\
\hline & Jumlah & 400 & 100 \\
\hline
\end{tabular}

Berdasarkan Tabel 3 diketahui bahwa jenis kelamin responden sebagian besar adalah dengan persentase $67,80 \%$. Dengan demikian dapat disimpulkan bahwa pengguna layanan puskesmas lebih banyak dimanfaatkan oleh perempuan. Hal ini dimungkinkan karena layanan puskesmas adalah pada jam kerja, sedangkan laki - laki lebih banyak di tempat kerja pada jam kerja.

\section{PEMBAHASAN}

Berdasarkan uji regresi berganda didapatkan rata - rata skor penilaian kesehatan lingkungan puskesmas adalah 735,40 dengan standar deviasi 78,376. Rata - rata skor penilaian bangunan luar adalah 14,10 dengan standar deviasi 3,831, bangunan dalam rata rata 14,57 dengan standar deviasi 3,737, fasilitas sanitasi rata - rata 13,41 dengan standar deviasi 3,317 dan manajemen kebersihan dan ruang tambahan rata - rata 30,12 dengan standar deviasi 5,637. Hubungan antar variabel skor penilaian kesehatan lingkungan puskesmas dan bangunan luar adalah 0,218 yang berarti menunjukkan hubungan rendah. Arah hubungan positif menunjukkan semakin besar penilaian 
bangunan luar akan semakin membuat skor penilaian kesehatan lingkungan semakin besar juga.

Hal tersebut juga berlaku dengan hubungan skor penilaian dengan bangunan luar sebesar 0,439, dengan bangunan dalam gedung 0,459 , skor penilaian terhadap sanitasi 0,517 dan pelayanan terhadap skor penilaian 0,355 Artinya hubungannya rendah dan sedang. Karena korelasi antara skor penilaian kesehatan lingkungan dengan bangunan luar, bangunan dalam, sanitasi dan pelayanan semuanya rendah maka dapat disimpulkan pengaruhnya kecil.Persamaan regresi yang didapat $\mathrm{Y}=35,29$ $+0,935 \mathrm{X} 1+1,320 \mathrm{X} 2-0,808 \mathrm{X} 3+1,031 \mathrm{X} 4$.

Berdasarkan hasil uji Anova didapatkan nilai probabilitas atau sig adalah 0,000 lebih kecil dari 0,005. Hal ini berarti H0 ditolak atau maka dapat disimpulkan bahwa ada pengaruh secara signifikan antara variabel bangunan luar gedung, bangunan dalam gedung, fasilitas sanitasi dan manajemen puskesmas secara simultan atau bersama-sama terhadap variabel kesehatan lingkungan puskesmas.

Hal ini sejalan dengan penelitian yang dilakukan Mugeni (2013), yang berjudul pelaksanaan program Kesehatan Lingkungan Puskesmas di Kabupaten Tuban Provinsi Jawa Timur ( Analisis Lanjut Riset Fasilitas Kesehatan Tahun 2011 ) menyatakan bahwa program kesling puskesmas di Kabupaten Tuban masih belum dilaksanakan disemua puskesmas perkotaan maupun pedesaan.

\section{Pengaruh kondisi kesehatan lingkungan terhadap kepuasan responden}

Hubungan antara variable kesehatan lingkungan Puskesmas dengan kepuasan responden adalah 0,669. Hal ini menunjukkan pengaruh yang kuat antara variabelkesehatan lingkungan puskesmas dengan kepuasan responden yang datang berkunjung ke puskesmas.Arah hubungan yang positif menunjukkan semakin baik kondisi kesehatan lingkungan puskesmas semakin membuat kepuasan responden datang berobat semakin tinggi begitu juga sebaliknya. Persamaan regresinya adalah $\mathrm{Y}=201,650+7,517 \mathrm{X}$.

Tingkat signifikansi satu sisi menghasilkan angka 0,000 lebih kecil dari 0,05 sehingga hubungan korelasi antara kesehatan lingkungan puskesmas dengan kepuasan respondensangat nyata atau signifikans.R Square 0,448 atau koefisien determinasi berarti 44,8\% kepuasan responden dapat dijelaskan oleh variabelkesehatan lingkungan puskesmas sedangkan sisanya dijelaskan oleh sebab lain.

Hal ini sejalan dengan penelitian yang dilakukan oleh Kristiani (2006) di Puskesmas Karanganyar Kebumen tentang kepuasan responden yang berkunjung ke puskesmas menunjukkan hasil bahwa adanya hubungan antara aspek kenyamanan dengan tingkat kepuasan responden. Ada ketidakpuasan yang muncul pada responden di Puskesmas Karanganyar yang disebabkan oleh aspek kenyamanan yaitu waktu tunggu, kebersihan ruangan tunggu, artinya kurangnya kenyamanan yang dirasakan responden dapat mempengaruhi kepuasan responden

\section{Pengaruh kondisi kesehatan lingkungan dengan jumlah kunjungan responden}

Hubungan antara variabel kesehatan lingkungan Puskesmas dengan jumlah kunjungan responden adalah 0,628. Hal ini menunjukkan hubungan yang kuat antara variabel kesehatan lingkungan puskesmas dengan kunjungan responden yang datang berkunjung ke puskesmas. Arah hubungan yang positif menunjukkan semakin baik kondisi kesehatan lingkungan puskesmas semakin membuat kunjungan responden datang berobat semakin tinggi begitu juga sebaliknya. Persamaan regresinya adalah $\mathrm{Y}=612,295+$ $0,008 \mathrm{X}$.

Tingkat signifikansi satu sisi menghasilkan angka 0,002 lebih kecil dari 0,05 sehingga hubungan korelasi antara kesehatan lingkungan puskesmas dengan kunjungan responden sangat nyata atau signifikan. $R$ Square 0,394 atau koefisien determinasi berarti $39,4 \%$ kunjungan responden dapat dijelaskan oleh variabel kesehatan lingkungan puskesmas sedangkan sisanya dijelaskan oleh sebab lain.

Berdasarkan hasil penelitian ini diketahui bahwa kunjungan responden dipengaruhi oleh kondisi kesehatan lingkungan puskesmas sebesar $39,4 \%$, sedangkan sisanya $60,6 \%$ oleh sebab lain. Berdasarkan karakteristik responden, dominasi pekerjaan sebagai ibu rumah tangga menggambarkan status ekonomi responden yang sebagian besar berada di kelas menengah kebawah sehingga 
responden tidak memiliki ekspektasi berlebih terhadap layanan yang membuat mereka dapat menerima keterbatasan fasilitas fisik kesehatan lingkungan di puskesmas.

Penelitian ini juga menemukan adanya pengaruh tidak langsung dari faktor empati terhadap minat kunjungan yang disebabkan oleh kepuasan responden. Indikator-indikator faktor empati yang menekankan betapa besarnya peran karyawan dalam menjalin komunikasi efektif terhadap responden sebagai salah satu cara meningkatkan kualitas layanan. Di lain pihak, dasar dari loyalitas sejati terletak pada kepuasan pelanggan, dimana kualitas layanan menjadi input utamanya. Pelanggan yang sangat puas akan berminat melakukan kunjungan ulang.

Hal ini sejalan dengan penelitian yang dilakukan oleh Elisabeth (2012), yang menyatakan bahwa ada hubungan antara kepuasan responden dengan tingkat loyalitas responden di poli rawat jalan Rumah Sakit Ibu dan Anak Bunda Sejati, Tangerang. Sedangkan sifat hubungan adalah positif karena nilai $r$ positif, berarti semakin tinggi atau semakin memuaskan pelayanan rawat jalan maka semakin tinggi pula loyalitas responden di poli rawat jalan RSIA Bunda Sejati. Respondenakan merasa sangat tidak puas apabila hasil pelayanan yang diberikan/didapatkan responden jauh dibawah harapannya, jika hasil pelayanan yang diberikan belum memenuhi harapan responden maka respondenakan merasa tidak puasterhadap pelayanan yang diterima responden. Pelayanan akan cukup memuaskan jika pelayanan yang diberikan sudah memenuhi sebagian harapan responden. Pelayanan akan memuaskan apabila pelayanan yang diberikan sudah memenuhi harapan rata-rata responden, sedangkan responden akan merasa sangat puas apabila pelayanan yang diberikan melebihi apa yang diharapkan responden.

\section{SIMPULAN}

Dari hasil penelitian ini dapat
disimpulkan bahwa kondisi kesehatan
lingkungan puskesmas berpengaruh secara
signifikan terhadap kepuasan dan jumlah
kunjungan pada puskesmas. Namun angka
persentase pengaruh masih cukup rendah artinya
banyak faktor lain yang lebih berpengaruh pada
kepuasan dan jumlah kunjungan pada

puskesmas. Dengan kondisi demikian maka disarankan agar pemerintah meningkatkan kualitas kondisi kesehatan lingkungan dan untuk peneliti selanjutnya agar meneliti faktor - faktor lain yang mempengaruhi terhadap kepuasan dan jumlah kunjungan pada puskesmas dan akhirnya dapat meningkatkan kualitas layanan puskesmas yang kesehatan masyarakat pada umumnya.

\section{UCAPAN TERIMA KASIH}

Penulis mengucapkan terima kasih kepada Pemerintah Provinsi Riau dalam hal ini Dinas Kesehatan Provinsi Riau, Pemerintah Kota Pekanbaru melalui Dinas Kesehatan Kota Pekanbaru, Puskesmas se-Kota Pekanbaru dan pengunjung serta pasien yang bersedia menjadi responden, serta pihak - pihak yang membantu sehingga penelitian ini dapat berlangsung dengan baik dan lancar.

\section{DAFTAR PUSTAKA}

Aer S (2015), Analisis Kepuasan Pasien Rawat Jalan Peserta Jaminan Kesehatan Nasional (JKN) di Rumah Sakit Umum Daerah (RSUD) Kabupaten Brebes. Universitas Negeri Semarang. Semarang

Alamsyah, D dan Muliawati,R (2013) Pilar Dasar Ilmu Kesehatan Masyarakat . Yogyakarta: Medical Book

Badan Penyelenggara Jaminan Sosial,2015, Penyelenggaraan BPJS di Kota Pekanbaru tahun 2015, Pekanbaru.

Dinas Kesehatan Provinsi Riau, 2015.Profil Dinas Kesehatan Provinsi Riau Tahun 2015, Pekanbaru

Dinas Kesehatan Kota Pekanbaru. 2016. Profil Dinas Kesehatan Kota Pekanbaru Tahun 2016, Pekanbaru

Djojosugito, Ahmad, 2001, Kebijakan Pemerintah dalam Bidang PelayananKesehatan Menyongsong AFTA 2003, www. Pdpersi.co.id

Elisabeth J. 2012. Hubungan Antara Kepuasan Pasien Dengan Tingkat Loyalitas di Poli Rawat Jalan Rumah Sakit Ibu dan Anak Bunda Sejati, Tangerang

Harianto, Nana Khasanah, dan Sudibyo Supardi. 2005. Kepuasan Pasien Terhadap Pelayanan Resep Di Apotek Kopkar Rumah Sakit Budhi Asih Jakarta. 
Idawani, 2001, Hubungan antara Mutu dan Cakupan Pelayanan Unit Rawat Jalan Puskesmas di NAD. Banda Aceh

Kartika Yanidrawati, 2010, Hubungan Kepuasan Kerja Dengan Kinerja Perawat Di Ruang Rawat Inap Rumah Sakit Umum Daerah Kabupaten Bekasi, Jawa Barat

Kemenkes RI, 2006, Pedoman Penyelenggaraan Kesehatan Lingkungan Puskesmas,Dirjen P2PL, Jakarta.

Kemenkes RI, 2009, Undang - undang tentang Kesehatan,Dirjen P2PL, Jakarta.

Kemenkes RI, 2014, Peraturan pemerintah tentang Kesehatan Lingkungan,Dirjen P2PL, Jakarta.

Kotler, 2009, A Meta-Analysisto Review Organizational Outcomes Related to Charismatic Leadership,Canadian Journal of Administration Sciences

Kristiani, Yohanita Rini; Tjahjono Kuntjoro; dan Adi Utarini. 2006. Pengembangan Desain Mutu Pelayanan Rawat Inap Puskesmas Karanganyar Kebumen. Kebumen

Mote. 2008. Analisis Indeks Kepuasan Masyarakat (IKM) Terhadap Pelayanan Publik Di Puskesmas Ngesrep Semarang. Tesis. Semarang: Universitas Diponegoro

Muliaddin, Ali Ghufron Mukti, dan Nanis Budiningsih. 2005. Analisis Pembiayaan Kesehatan Keluarga Miskin Di Kota Buton Provinsi Sulawesi Tenggara

Nita Prama,2009. Pengaruh Sampah terhadap Kualitas Lingkungan di Sungai Apung. Universitas Muhammadiyah Sumatera Utara, Medan

Nurba. (2012). Analisis Tingkat Kepuasan Pelayanan Publik Pada Puskesmas Loa Janan.

Parani, 1997. Manajemen Mutu Pelayanan Kesehatan, Surabaya Airlangga University Press

Permenkes RI, 2014, Pusat Kesehatan Masyarakat,Menkes RI, Jakarta.
Priatno P, 2014, Faktor - faktor yang berpengaruh terhadap keberhasilan program sanitasi total berbasis masyarakat (STBM) di kota Tasikmalaya, Universitas Brawijaya, Surabaya.

Slamet, Juli S, 2004, Kesehatan Lingkungan, Gajah Mada University Press, Yogyakarta.

Shinta A, 2014, Hubungan mutu pelayanan kesehatan dengan tingkat kepuasan pasien rawat inap di Puskesmas Halmahera Kota Semarang tahun 2014,Universitas Negeri Semarang, Semarang.

Sornauli S, 2009, Hubungan kualitas pelayanan dan kepuasan pasien dengan kunjungan di balai pengobatan gigi Puskesmas Kota Pekanbaru, Universitas Sumatera Utara, Medan.

Subekti, Dede. 2009. Analisis Hubungan Persepsi Mutu Pelayanan dengan Tingkat Kepuasan Pasien Balai Pengobatan (BP) Umum Puskesmas Di Kota Tasikmalaya

Sugiharto Mugeni, 2013, Pelaksanaan Program Kesehatan Lingkungan Puskesmas di Kabupaten Tuban Provinsi Jawa Timur. Surabaya

Tjiptono, 2008, Metodologi Penelitian Bisnis UntukAkuntansi \& Manajemen, BPFE Yogyakarta

Umar, 2003, Biaya atau Kepuasan Pasien?, www. Pdpersi.co.id

Undang - Undang Kesehatan Nomor 36 tentang Penyelenggaraan Kesehatan Lingkungan pasal 162,Menkes RI

Wijono. (2008). Manajemen Mutu Rumah Sakit dan Kepuasan Pasien. Surabaya: CV. Duta Prima Airlangga

Zeithaml, Bitner, 2003, Communication and Control Processes in the Delivery of Service Quality; Journal of Marketing, Vol. 52 